\title{
Film Industry Channel Innovations Or With Digital Movie Transmission: Will Popcorn Prices Drop At Movie Theaters?
}

Judy Dietert (Email: jd13@business.swt.edu), Southwest Texas State University J.R. Minifie (Email: jm13@business.swt.edu), Southwest Texas State University Mike Keeffe (Email: mk02@business.swt.edu), Southwest Texas State University

\begin{abstract}
Changes in the film industry are occurring and are expected to continue to change due to the internet and other new technology. This manuscript investigates the distribution system of the film industry and how it is being impacted by these changes. Will the stadium seating movie theater go by the wayside as the old drive-in theaters? Will distribution of movies be downloaded as common as music is now? These and more questions are addressed in this research effort.
\end{abstract}

\subsection{Introduction}

0 $\mathrm{n}$ a recent visit to a movie theater, with the stadium seating so that everyone has an unobstructed view of the

screen, the price of two movie tickets was less than the two soft drinks and popcorn purchased at the concession stand. Our first reaction was that this was outrageous. How could the price of popcorn be so high at the movie theater? The quality of the popcorn did not seem to be better than that bought at other venues. Briefly, the thought of not having popcorn at the movie theater crossed our minds. Again, it was only a brief thought. How can one watch a movie, with stadium seating, digital surround, and not have popcorn? This phenomenon had to be investigated.

This manuscript is the investigation into the price of popcorn at movie theaters. We will first discuss our findings on the price issue of popcorn. Our search of popcorn prices led us to the film industry distribution system. We will then discuss this distribution system and how the technology is changing this distribution system. Finally, we will present our view of the future of the movie industry.

\subsection{Theater Concessions}

Movie theater owners joke that they are in the candy business since most of the money from movie ticket sales goes back to the movie studio. Theaters negotiate film distribution deals through a film booker. The film booker leases a movie to a particular theater for a set number of weeks. The percentage of the ticket sales that the movie theater receives for a film increases each week that the movie is shown in the theater. During a film's opening week, the movie theater may receive from 20 to $30 \%$ of the gross box office sales. By the fifth or sixth week, the percentage that the movie theater receives may grow to $65 \%$.

Obviously, the movie theater does not make very much during the first couple of weeks of a film's initial release. The longer that a theater keeps a film, the more box office revenues it can keep. But most movies only stay out in release for a few weeks. The fist two to three weeks are all that is needed to forecast accurately the overall

Readers with comments or questions are encouraged to contact the authors via email. 
box office revenue pattern for a movie, which in turn, can be used to forecast other distribution mode revenues. [14] since the majority of a film's revenue is generated in these first initial weeks, theater owners are counting on these movie goers stopping at the concession stand on their way to their seats in the theater.

So where do movie theaters generate their revenue? It is estimated that concessions generate $30 \%$ of revenues, with box office accounting for 65\%, and video games the remaining 5\%. [9] However, the profit figure of concessions may be as much as $80 \%$. [6] concession companies may pay theater owners up front to run this part of the business. Theater owners also receive revenue from movie studios for showing trailers. Theater owners have to call the film companies each day to report the number of people who saw each trailer in order to collect their revenues. In addition, many theaters will show advertisement slides before movies. The theaters normally split the $\$ 50-\$ 100$ fee for ad slides with the local advertising agent.

The question that many theaters face is why do theater owners have to charge so much for their popcorn? Why do theater owners make so little of the initial ticket sales for a movie? The fastest-growing expense for movie studios these days comes from the increased marketing costs. Marketing expenses have increased more than $80 \%$ in the past 5 years. [16] For instance, fox made $\$ 4.4$ billion from box-office smashes such as Titanic and There's Something About Mary, yet it spent an estimated \$1.7 billion to make and market those and other films. [16] Then there is the cost of the film itself. Each movie costs about $\$ 2000$ for each print, with estimated shipping costs for each film to a theater at about $\$ 300$, resulting in a $\$ 1.2$ billion annual distribution cost for the movie industry. [13] film duplication can run to $10 \%$ of the total production costs of a movie based on an average budget. [4] Movie studios, knowing that the demand is greater for a film in the first initial weeks, try to recover much of these costs through a high percentage of the revenue during the first two weeks of a movie release.

\subsection{Film Distribution}

The movie industry is looking to change the way films are distributed to movie theaters in order to cut these costs. In 2000, the first use of satellite delivery of a feature film to a theater in high-resolution digital cinema format occurred. The movie bounce "bounced off" a communications satellite and into the AMC empire theatre in New York's times square. The delivery of bounce was declared a landmark day for the movie business as a better means to distribute motion pictures. [13] This satellite transmission took 10 hours because of the large size of the compressed file at about 50gb. It is expected that once the system becomes commercially available the 10 hour transmission time would deliver the same movie to 2000 theaters. Satellite delivery would result in film distribution costs to be cut to around $\$ 500$ million. Not only would there be distribution cost savings, the quality of the digital version would be better than film. With digital cinema, theater goers would enjoy pristine images each and every time they would go to the theater.

Electronic cinema appears to be the solution for cutting production and distribution costs significantly. The electronic cinema replaces the film in movie theaters with a form of high-resolution video. This change is needed in order to make theatrical releases more profitable. The problem with this new mode of distribution and delivery is betting that a satellite network and technology will be in place in order to accomplish this new distribution system.

Digital copies on optical disc could be produced and distributed in the traditional manner of film copies at a fraction of the cost of film duplication. Electronic distribution at the current level of proposed resolution would require special equipment for real-time transmission and for storing and forwarding of the film over reasonable lengths of time. Currently, only fiber rings and broadband wireless could accommodate such throughputs on the local level. Neither type of network is close to being omnipresent in the US or elsewhere. Thus distributors must use satellite.

Going from film to digital is the largest revolution in movies since the inception of talkies back in 1927. Movie studios and distributors could save hundreds of millions of dollars each year on processing and distributing movies. In order to achieve these results, movie theaters must invest in digital system projectors. The quality of the digital projection has taken years to get to the same level as film, thus making moviemakers skeptical of its use in movie making. Another drawback to digital projection is the fact that the potential movie base theater chains like 
Loews Cineplex and general cinemas are not financially able to purchase the expensive equipment needed for digital transmission and projection.

This technology is not sitting around idle while waiting for movie theaters to become more profitable. Digital production companies, in looking for another market for their product, have targeted the airline industry. The satellite system division of the Seattle-based the Boeing Company, has targeted the aviation industry regarding potential broadband application to enhance airline and passenger security. [13] They are also using this system to assist airline passengers to stay globally connected at all times by developing a communications network that will revolutionize the way people travel. Air travelers will be provided with high-speed data communication services by means of a space-based network for the same price as cellular phone service. Currently, Scandinavian airlines system and Lufthansa's have selected Boeing as their mobile connection service provider.

The Motion Picture Association of America (MPAA) doesn't want piracy to be a part of the digital evolution. It has been estimated that by the end of 2002, more than a million movies will be downloaded, resulting in a potential loss of billions to the film industry. [10] The question becomes, will the film industry follow the music industry in how they address such issues. Terry Semel, of Yahoo! Feels that the music and movie industries are wasting energy worrying about piracy concerns when they should be using this as a chance to explore new opportunities for development. Initial litigation by movie studios was not sufficient since for every digital dealer who was shut down, another emerged to take its place. Other efforts to develop security measures have failed due to the fact that there are enough teens out there with ample time to crack any code or security measure developed.

The web is being used in a number of different ways in order to reach consumers. Currently, Columbia Tristar and Buena Vista are selling movie tickets over the web. Although these studios do not try to measure the efficiency of their web sites, ticket sales would be a good measurement of how well a site works. Small independent film makers (Indies) are using web sites to spread the buzz about their film and alert fans to sometimes sporadic screenings. These Indies can reach potential consumers without an expensive promotional budget. One such Indie, creative thinking, felt that the web site had increased attendance by 15 to $20 \%$ at their movie screenings.

Research comparing internet users with non-users found that word of mouth was by far the most important source of movie information for both on-line and off-line movie goers. Only $9 \%$ of the internet users said that the internet and online web sites were important. [5] Of the consumers who did go online to decide what movie to see, the top four web site destinations were Yahoo! American Online, Excite, and E! Online. Still, movie studios feel that the web can help a movie to open strongly. Unfortunately, while it may be easy to track what people do while they are on the web, it is difficult to correlate a web ad with actual movie ticket revenue.

Other movie studios are reacting by directly litigating small time dealers to implementing their own online distribution system to combat digital piracy. Atomshockwave Corp. Offers Games, Short Films, and Animation to Businesses and Consumers Via the Web, Broadband Networks, and even on mobile computing devices. Currently, they get about 2 million unique visitors every month. They offer online users free access to more than 1500 short films that can be viewed on Real Player or Windows Media Player.

Full feature films, by Top Film Distributors, are supporting Video-On-Demand (VOD) services. Consumers can already buy and rent movies over the internet by downloading to a personal computer for viewing from several different web sites. Intertainer, Sightsound, and Cinemanow offer films as rentals to viewers for payper-view or as monthly subscribers. Some rental services allow for a 24 hour viewing period of a downloaded film. The current downloading time, for a full length feature, with a DSL connection, is about 10 hours. The viewer has 24 hours to view the movie as much or as little as they desire. The file is no longer accessible once the time period has expired. It should be noted that these downloaded films also pay the price in terms of compromised sound quality.

Illegitimate VOD Sites offer films for about \$1each. Early in 2002, The International Arm of the MPAA shut down Movie88.com based out of Taiwan. But only months later, another illegitimate site based in Iran, Film88.Com, Sprouted Up. Since the United States doesn't have diplomatic relations with Iran, The International 
Arm Of The MPAA was not able to directly shut down this site. In the end, the MPAA prevailed by contacting the internet provider in the Netherlands that was hosting film88.com's content.

In general, all of Hollywood's internet distribution plans have lagged far behind online competitors since many major movie studios are focusing on cable and satellite services linked to TV, rather than internet services. Some consumers are opting for viewing brand-new film releases on their home theater system. In order to accomplish this, homes need to have web-to-TV links. Families can pop their own popcorn and enjoy a film on their monster-screen home TV for about $\$ 29.95$. The advantage for movie studios is huge for these options. Movie studios will receive $\$ 28$ of the $\$ 29.95$ and they can sell their own ads or trailers customized to the consumer buying the movie. Currently, Pay-Per-View events are already taking advantage of the home theater. Boxing and wrestling shows routinely attract several million paying consumers. This may be a great advantage for the Indie movie producers to get their films to audiences and bypass the movie distributors.

\subsection{Conclusion}

The movie theater business does not follow the normal convention of other products or services. The product quality of movies is notoriously unreliable. In the case of movies, even the most highly praised product is often disappointing. "if bath soap had a similarly dismal track record, most people would walk around unwashed." [8] the re-release of the Star Wars Trilogy demonstrates that some people will go to a movie theater even when a video tape of a movie exists.

Will movie theaters go the way of the drive-in? Not as long as consumers wish to see tom cruise fifty feet high with digital surround sound and armfuls of concession stand goodies. What we will see in the movie industry is a change in the distribution paradigm first, similar to the record business because of Mp3. Movie studios will change how they evaluate audience interaction, co-marketing opportunities, tie-ins, prop sales at online auctions, and even testing of the movie online.

Can we expect popcorn prices to drop in the near future? Our guess is that as long as the movie studios distribute movies on film, the distribution cost will continue to keep popcorn prices rising. Let's only hope that once the initial cost of digital equipment is recovered by movie theaters, owners will consider dropping popcorn prices. Until then, the stop at the concession stand on the way to your theater seat will continue to cost you more than your price of admission.

\section{References}

1. $\quad$ Pack, Thomas (May 2002) Atomshockwave Corp.: Short Movie Supplier Econtent, Vol. 25, No. 5, Pg. 5051

2. Wahl, Andrew (Sept. 3, 2001) Cinemasaurus Canadian Business, Vol. 74, No. 16, Pg. 46-49

3. Birkmaier, Craig (August 2002) Surround And Conquer: Digital Audio Technology, Broadcast Engineering, Vol. 44, No. 8, Pg. 14.

4. Sweeney, Dan (July 15, 1999) Can Satellites Go Hollywood? America's Network, Vol. 103, No. 11, Pg. 20-23.

5. $\quad$ Kuchinskas (Feb. 8, 1999) If Studios Build Them ... Mediaweek, Vol. 9, No. 6, Pg. 38-40.

6. Gwyther, Matthew (Mar. 1999) The Big Box Office Bet Management Today (London), Pg. 45-50.

7. Lobb, Annelena (April 3, 2000) Think You'd Like To Run A Movie Theater? Better Butter Up On Snack Sales Cnnmoney, The Internet (11/15/02): Money.Cnn.Com/2002/03/08/Smbusiness/Q_Movies

8. Dolliver, Mark (April 3, 2000) Or Maybe They're Addicted To Movie-Theater Popcorn Adweek, Vol. 41, No. 14 , pg. 46

9. Mcnary, Dave (March 14, 1998) Candy Is Dandy For Movie Theater Profits, Say Owners, Analysts Daily News (Los Angeles, Ca) Pg. B1.

10. Levack, Kinley (Sept. 2002) Digital Darwinism: Piracy Pushes Progress Econtent, Vol. 25, No. 9, Pg. 6-9.

11. Pack, Thomas (May 2002) Atomshockwave Corp.: Short Movie Supplier, Econtent Vol. 25, Iss. 5; Pg. 5052.

12. Whal, Andrew (Sept. 3, 2001) Cinemasaurus, Canadian Business (Toronto), Vol. 74, Iss. 16, Pg. 46-50. 
13. [Brewin, Bob (Nov. 27, 2000) Satellite Delivery Of Feature Films Debuts, Computerworld (Framingham) Vol. 34, Iss. 48, Pg. 12.

14. Lehmann, Donald R (July 2000) Sale Through Sequential Distribution Channels: An Application To Movies And Videos, Journal Of Marketing (Chicago), Vol. 64, Iss. 3; Pg. 16-34.

15. Goldberg, Aaron (March 2000) The Big Screen's Web Shakeup, Upside (Foster City), Vol. 12, Iss. 3; Pg. 30 .

16. Grover, Ronald (November 1, 1999) Fox's New Star: The Internet: The Studio Uses It To Cut Costs And Pick Sales Strategies, Business Week (New York) Iss. 3653; Pg. Eb42.

Notes 
Notes 